\title{
2012 Dahlberg Award Winner: Dental morphological variation among six Pre-Hispanic South American populations with implications for the peopling of the New World
}

Alejandra Ortiz

New York University, New York, NY 10003

Keywords: Discrete dental traits, ASUDAS, Dental variation, South American Indians

ABSTRACT The analysis of the human dentition provides important information on the origins and dispersals of the first American inhabitants. However, most of this work has focused on North America, whereas less research has been devoted to variation within Central and South America. This study examines the permanent dentitions of 340 individuals from six pre-Hispanic South American populations and places them in the broader context of the peopling of the New World. Non-metric dental data were collected using the Arizona State University Dental Anthropology System (ASUDAS). Intra- and inter-regional comparisons were assessed using the Mean Measure of Divergence statistical program.

Since Columbus reached the New World in 1492 and found it already inhabited by humans, one of the most enduring debates among scholars and early natural historians has centered on the origins of the first American inhabitants. Until the 1980s, the predominant view was that one single founding group, represented archaeologically by the Clovis culture, first entered the Americas after the last glacial maximum (LGM) via the Bering land bridge (Martin, 1973; Lynch, 1983). The Clovis-first model hypothesized that around 13,000 years ago people migrated from Siberia to Alaska tracking big game animal herds and that in a few millennia spread rapidly from Beringia to Tierra del Fuego (Dillehay, 1999, 2000, 2009; Meltzer, 2004; Goebel et al., 2008). In accord with this model, Greenberg et al. (1986) published a widely cited, yet highly controversial, three-wave model for the peopling of the New World. Based on the linguistic, dental and genetic evidence available at that time, they argued that the first Americans came from Northeast Asia in three separate waves of migration. Following Greenberg et al. (1986), the first migration would have involved the ancestors of Amerind-speaking populations from South, Central and most of North America. These first settlers would have been associated with the big-
All samples are characterized by relatively high frequencies of UM1 enamel extension and LM1 deflecting wrinkle and low frequencies of UM1 cusp 5 and LM2 Y-groove pattern. Although preliminary, results indicate that populations from Chile, Venezuela and Peru-Northern Coast are dentally similar and follow the Sinodont dental pattern. The PeruSouthern Highlands sample is the most divergent of the South American groups examined, showing the closest affinities with Sundadonts. Finally, no clear pattern was found for Bolivia and PeruAmazonian Andes, as most of their trait frequencies fall within the range of overlap between Sinodont and Sundadont populations.

game hunting Clovis culture and its rapid spread throughout the American continent. The second migratory wave would have been associated with the ancestors of $\mathrm{Na}$-Dene speakers from the western half of the North American subarctic, including the North Pacific Coast. The third and last migratory wave from Northeast Asia would have involved the ancestors of Aleut-Eskimo populations, occupying territories from western Alaska to eastern Greenland.

Over the past 25 years, several archaeological sites in the Arctic and the Americas have provided compelling evidence for human occupation predating Clovis (e.g., Dillehay, 1997, 2000; Adovasio et al., 1998; Pitulko et al., 2004; Goodyear, 2005). Relatively recent genetic and craniofacial studies have also brought both the Clovis-first and threewave models into question. For example, molecular data suggest a single and early (i.e., pre-Clovis) migration for the peopling of the New World (Bonatto and Salzano, 1997; Schurr, 2004; Zegura et al., 2004; Tamm et al., 2007; Wang et al., 2007; Fagundes et al., 2008a,b). Mitochondrial DNA (mtDNA) analyses have revealed that the majority of Native Americans (including Na-Dene and Aleut-Eskimo) belong to five distinct mtDNA haplogroups, which have been identified as A-D and 
X (Schurr, 2004). Furthermore, Zegura et al. (2004) demonstrated that these populations exhibit, almost exclusively, Y-chromosome haplogroups $Q$ and $\mathrm{C}$. Although all these lineages can be traced back to modern Northeast Asians, recent genetic data from Native American samples reveal the presence of autochthonous mutations of particular mtDNA and Y-chromosome haplogroups, which cannot be explained by old Clovis paradigms (Tamm et al., 2007; Fagundes et al., 2008a,b). In this regard, and although the exact pre-Clovis timing of migration remains controversial (for reviews see Schurr, 2004), geneticists seem to concur that a population expansion with its roots in Beringia occurred by the end of the LGM, followed by a rapid settlement of the continent along a Pacific coastal route (Bonatto and Salzano, 1997; Tamm et al., 2007; Wang et al., 2007; Fagundes et al., 2008a,b).

Research on craniofacial variation among early American populations also suggests an early date for the peopling of the New World (Powell and Neves, 1999; Pucciarelli et al., 2003; Neves et al., 2003; Neves and Hubbe, 2005; Hubbe et al., 2011). Contrary to interpretations based on molecular markers, these studies have proposed that the New World was initially occupied by two biologically and chronologically distinct human groups. Advocates of this two-wave model argue that the ancestors of a morphologically generalized (or non -specialized Mongoloid) "Paleoamerican" population first migrated to the New World and were later replaced by the ancestors of the "Amerindians," who carried the highly derived Northeast Asian (or Mongoloid-Sinodont) phenotype. Lahr (1995) considers that the high level of diversity observed among Native Americans, including both Paleoamericans and Amerindians, can be explained by a single, albeit not necessarily earlier, migration of non-specialized Mongoloids that entered the Americas before many Mongoloid -Sinodont traits spread throughout Northeast Asia. More recently, González-José et al.'s (2008) analysis of modern human cranial variation also suggests a single origin for all Native Americans. Contrary to Lahr (1995), however, they propose a pre-Clovis occupation of the New World and emphasize the critical role that Beringia played in shaping the Native American pattern of variation.

Although considerable advances have been made since the publication of Greenberg et al.'s
(1986) model, our understanding of the real extent of dental morphological variation across the Americas remains elusive. Turner's pioneering research on dental morphology demonstrated the usefulness of non-metric traits for assessing human biological relationships and reconstructing human population history (Turner, 1984, 1986, 1987, 1990, 1993; Scott and Turner, 1997). Based on his work, however, Native Americans have been regarded as a rather biologically and phenotypically homogeneous human group, sharing a strict Sinodont dental pattern (but see Haydenblit, 1996). Nevertheless, the apparent homogeneity of Native American populations, and their close association with modern Northeast Asians, may be attributed to the fact that our characterization of Native American dental morphology has largely been based on North America (Dahlberg, 1951, 1963; Moorrees, 1957; Sofaer et al., 1972; Turner, 1983, 1990, 1993; Scott et al., 1983). In fact, relatively little work has concentrated on Central (Baume and Crawford, 1978; Haydenblit, 1996) and South (Goaz and Miller, 1966; Kieser and Preston, 1981; Turner and Bird, 1981; Sutter and Verano, 2007) America. Furthermore, research in Central and South America has generally focused on a limited number of dental traits in only a few populations. Thus, attempts to assess biological affinities between South Americans and other world populations have been relatively rare (e.g., Turner and Bird, 1981; Turner, 1984, 1986; Sutter, 2005; Hanihara, 2008).

To partially reconcile interpretations derived from dental morphology with those based on relatively recent craniofacial and genetic data, the present study reanalyzes dental affinities in the New World, with special attention to South American populations. Two hypotheses are tested. Hypothesis 1: if South Americans are dentally homogeneous, no significant differences among groups are predicted. Hypothesis 2: if all Native Americans have a relatively recent Northeast Asian origin, a shared Sinodont dental pattern across all samples is predicted. The specific goals of this study are to: (1) describe South American dental morphology; (2) determine biological affinities among South American populations; and (3) compare their morphology with published data from major world populations showing either the Sinodont or Sundadont dental pattern. Ultimately, I analyze dental morphological data to enhance our understanding 
TABLE 1. South American samples used in this study

\begin{tabular}{|c|c|c|c|}
\hline Sample name & Code & $\mathrm{n}$ & Time period \\
\hline Peru - Southern Highlands & PSH & 61 & pre- or proto-Hispanic \\
\hline Peru - Northern Coast & $\mathrm{PNC}$ & 37 & $\begin{array}{l}\text { from pre-Ceramic Period to Initial Period- } \\
\text { Cupisnique times (ca. } 3500-200 \text { B.C.) }\end{array}$ \\
\hline Peru - Amazonian Andes & PAA & 62 & $\begin{array}{l}\text { from Late Intermediate Period to early Spanish post- } \\
\text { contact times (ca. } 800 \text { - } 1532 \text { A.D.) }\end{array}$ \\
\hline Chile & $\mathrm{CHI}$ & 41 & $\begin{array}{l}\text { from pre-Ceramic Period to early Spanish post- } \\
\text { contact times (ca. } 3500 \text { B.C.- } 1532 \text { A.D.) }\end{array}$ \\
\hline Venezuela & VEN & 32 & pre- or proto-Hispanic \\
\hline Bolivia & BOL & 107 & Late Intermediate Period (ca. 1000-1400 A.D.) \\
\hline TOTAL & & 340 & \\
\hline
\end{tabular}

$\mathrm{n}=$ number of individuals examined

of South American origins and the initial peopling of the New World.

\section{MATERIALS AND METHODS}

\section{Study Sample}

This study examined the permanent dentitions of 340 individuals from six pre- or proto-Hispanic South American populations. The geographic origin and number of individuals in each sample are presented in Table 1. Figure 1 illustrates the geographical range for each sample. Except for the Peru-Amazonian Andes sample, which is curated at the Instituto Nacional de Cultura (Chachapoyas, Peru), all data were collected on skeletal remains housed at the American Museum of Natural History (New York, USA). In some cases, small collections were pooled to increase the sample size of specific regional populations. Further details of sample composition are provided below.

Peru - Southern Highlands (PSH). This sample includes individuals from Apurimac $(n=53)$ and Puno $(n=8)$. Both sites are located in the southern highlands of Peru. All specimens belong to the von Luschan collection. The time period during which these populations lived is not mentioned on museum records. However, some specimens present intentional cranial deformation and/or cranial trephination, suggesting that these populations lived during pre-Hispanic times or had limited Spanish influence. ${ }^{1}$

Peru - Northern Coast (PNC). A total of 37 preHispanic individuals recovered by Junius Bird (1985) during his expedition to the Chicama, Virú and Moche valleys in the northern coast of Peru make up this sample. The majority of specimens (n = 32) came from the Huaca Prieta archaeological site and belong either to the pre-Ceramic Period (ca. 3500-1300 B.C.) or the Initial PeriodCupisnique times (ca. 1300-200 B.C.). No specific cultural affiliation has been attributed to the remaining five individuals.

Peru - Amazonian Andes (PAA). This sample consists of 62 individuals from the Chachapoya culture, which occupied the territory between the northeastern flank of the Andean Cordillera and the northwestern portion of the Amazonian forest. All individuals were recovered from primary or secondary burials at the archaeological complex of

1 Artificial cranial deformation and cranial trephination were regular practices in pre-Hispanic South America (Imbelloni, 1925; Munizaga, 1987). Although these cultural practices have been forbidden since 1585, due to the Spanish influence over the Andean region (Hoshower et al., 1995), a few cases have been reported in relatively isolated post-contact indigenous groups (Bandelier, 1904; Weiss, 1961; Tommaseo and Drusini, 1984). 
Kuelap and have been dated to ca. 800 - 1532 A.D. (Schjellerup, 1997).

Chile (CHI). This sample consists of 41 individuals from north-central Chile. The majority of the specimens analyzed $(n=24)$ was recovered by Bird during his expedition to Chile (Bird, 2006). The remaining 17 individuals belong to different museum collections. All specimens date between the pre-Ceramic Period (ca. 3500-1300 B.C.) and early Spanish post-contact times (ca. 1532 A.D.).

Venezuela (VEN). This sample consists of 32 individuals. Most $(\mathrm{n}=26)$ are from La Mata, an artificial mound situated on the shores of Lake Valencia in the Maracay region (Bennett, 1937). The La Mata site was excavated by archaeologist Wendell Bennett during his 1932 expedition, where several pre-Hispanic burials with no specific cultural affiliation were recovered. The remaining six individuals came from Maracaibo and belong to the von Luschan collection.

Bolivia (BOL). The Bolivian Altiplano is represented by a sample of 107 individuals. They are dated to the Late Intermediate Period, which extends from approximately 1000 to 1400 A.D. (Bandelier, 1910). All specimens were recovered by Adolph Bandelier during his expedition to South America from1894 to 1898.

\section{Scoring Procedures and Statistical Analysis}

Dental morphological affinities among samples were assessed using the Arizona State University Dental Anthropology System - ASUDAS (Turner et al., 1991). To avoid misleading results attributed to European admixture, only presumed pre- or proto- Hispanic individuals were included and analyzed. Although data were collected on the complete set of ASUDAS crown and root traits, only 21 tooth-trait combinations were used in this study. These combinations focus on the key tooth sensu Dahlberg (1945), as well as traits whose sample sizes consist of at least three individuals in each group. Furthermore, features that were consistently absent across samples (e.g., UC Bushman canine) were removed from analysis. According to Irish (2010), dropping traits that are nondiscriminatory across samples is the standard procedure, as their inclusion does not effectively contribute to group differentiation. Teeth with occlusal wear or post mortem damage were analyzed to the extent

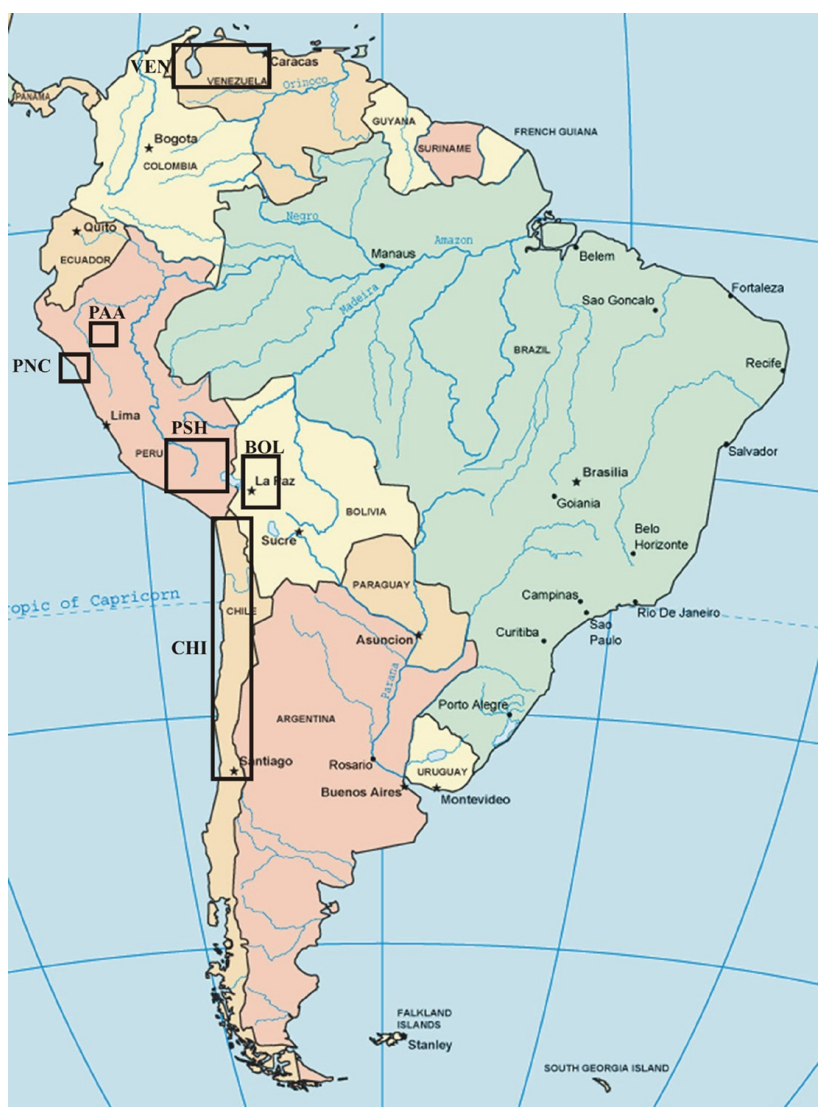

Fig. 1. Map of South America showing the geographical range of the six pre- or proto-Hispanic Andean populations used in this study.

that the trait observed was not obscured. Previous investigations demonstrated the lack of sexual dimorphism of non-metric dental traits (Turner, 1984; Hanihara, 1992; Irish, 1993, 1997; Scott and Turner, 1997), and thus males and females were combined in this study.

Trait frequencies were estimated using the individual count method of Turner and Scott (1977). This method suggests that the antimere exhibiting the strongest degree of trait expression is used in the analysis, as it is a more accurate indicator of the individual's genotype (Turner and Scott, 1977; Scott and Turner, 1997). Following Sjøvold (1977), trait expression was dichotomized into categories of presence or absence to facilitate multivariate statistical analysis. All traits were dichotomized at the standard breakpoints according to the ASUDAS (see Table 2). Levels of differentiation among samples were calculated using Smith's Mean Measure of Divergence (MMD) multivariate statistic. This method provides a quantitative estimate of biological divergence between two given samples based on the degree of similarity across 
the entire suite of traits (Berry and Berry, 1967; Sjøvold, 1977; Harris and Sjøvold, 2004; Irish, 2010). Thus, a smaller value indicates greater affinity between comparative groups. Divergence between two samples was considered significant at $p$ $\leq 0.025$, when the MMD value is greater than twice its standard deviation (Sjøvold, 1977). Small sample sizes were corrected using the Freeman and Tukey angular transformation. However, because of the correction factor, this transformation may yield negative MMD values (Berry and Berry, 1967; Sjøvold, 1977; Harris and Sjøvold, 2004). These negative values are statistical artifacts and indicate no meaningful divergence between two samples. Thus, the standard procedure is to set them at zero (Harris and Sjøvold, 2004; Irish, 2010).

Finally, to place the six South American samples examined in a global context, trait frequencies were compared to other populations exhibiting either the Sinodont or Sundadont dental pattern (sensu Turner, 1987, 1990). These included samples from North and Southeast Asia (Turner, 1984, 1987, 1990), North America (Turner, 1984, 1986), and Mesoamerica-Mexico (Haydenblit, 1996). All comparative data were scored using the ASUDAS. Special attention was initially given to the eight diagnostic traits of the Sinodont-Sundadont division proposed by Turner (1987, 1990): UI1 shoveling, UI1 double shoveling, UP3 root number, UM1 enamel extension, UM3 peg/reduced/congenital absence, LM1 deflecting wrinkle, LM1 root number and LM2 cusp number. However, the lack of radiographic analysis precluded accurate observations of "present, but unerupted UM3s", so this feature was not included. Trait selection for the inter-regional MMD analysis was based on the availability of published data with similar dichotomized breakpoints.

\section{Intra-observer Error}

Intra-observer concordance for the 21 dental traits was assessed by rescoring 30 (five per sample) of the 340 individuals originally examined. Scoring sessions were separated by five months. This analysis was performed by $\mathrm{AO}$ according to Nichol and Turner's (1986) recommendations. The percentage of disagreements (of any magnitude) between the two scoring sessions was $4.6 \%$. The percentage of disagreements of two or more grades between the first and second sessions was $0.3 \%$. Finally, the percentage of cases where traits after dichotomization would have been scored as "present" in one session and "absent" in the other was $1.9 \%$. All these values are similar to those reported by Nichol and Tuner (1986).

\section{RESULTS}

\section{Trait frequencies of early South Americans: Do they all follow the Sinodont pattern?}

Frequency comparisons of 21 discrete dental traits in six South American populations are summarized in Table 2. Examples of these traits in South American upper dentitions are provided in Figure 2. All samples are characterized by relatively high frequencies of UM1 enamel extension, LM1 deflecting wrinkle and LM1 cusp 6 (except for PSH), as well as low frequencies of UP3-UP4 odontome, UM1 cusp 5 and LM2 Y-groove pattern. They also show low to intermediate frequencies of LM1 cusp 7. Frequencies of occurrence of these traits fall within the range of variation of Sinodont populations (Turner, 1987, 1990; Scott and Turner, 1997). Furthermore, in accordance with the Sinodont dental pattern, South Americans exhibit high frequencies of UI1 shoveling, with the exception of PSH and BOL, whose intermediate frequencies of UI1 shoveling more closely approximate those of Jomonese and Ainu populations (Turner, 1987, 1990). While the incidence of UI1 double-shoveling is also high in the PNC, PAA and CHI samples, PSH, BOL and VEN have more Sundadont-like frequencies of occurrence of this trait. Moreover, except for BOL, all samples show high frequencies of four-cusped LM2 (or hypoconulid absence). The absence of the hypoconulid on LM2 is more common in Sundadont than in Sinodont populations (Turner, 1990). In general, there is a broad range of overlap between Sinodonts and Sundadonts regarding the incidence of multi-rooted UP3. The PSH, PNC and BOL samples exhibit intermediate frequencies of this feature, falling within this range of overlap. In contrast, multi-rooted UP3 does not frequently occur in CHI and VEN, and thus they more closely align with Sinodonts.

Except for BOL, all samples show intermediate to high frequencies of UM1 Carabelli's trait. This is surprising not only because trait presence was limited to grades 3-7 (as opposed to Turner's [1987] dichotomizing breakpoint of grades 2-7), but also 


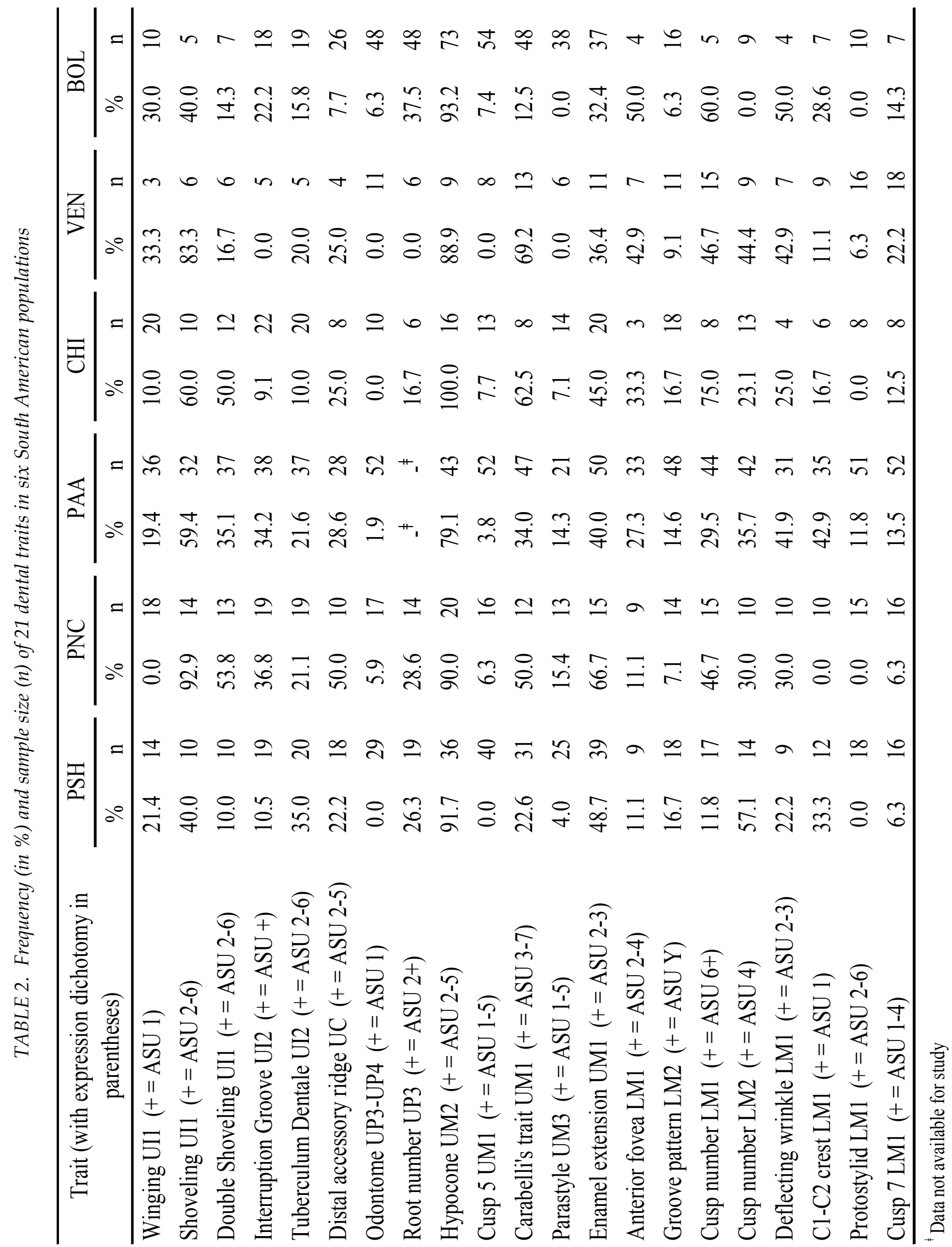


because similar levels of occurrence have been associated with European and African populations (Scott and Turner, 1997). Moreover, frequencies of LM1 protostylid are remarkably low in all South American groups examined. However, this can be attributed to the fact that, to avoid misleading assessments due to the presence of pit-like caries on the buccal groove, I did not include the ASUDAS grade 1 as part of the protostylid complex. Although Turner (1971) found the high incidence of three-rooted LM1 to be a distinctive Sinodont feature, this trait was invariably absent in all samples studied. These latter results, however, could be biased given that only loose molars or root sockets lacking teeth were recorded (i.e., no radiographic analysis was conducted).

\section{Mean measure of divergence intra-regional analysis}

Pair-wise comparisons for the six South American samples using the MMD statistical program are presented in Table 3. MMD values range from
0 to 0.229 , with a mean of 0.054 . In general, there are significant dental affinities among most of the samples examined, especially in PNC, CHI and VEN. The intra-regional analysis also suggests that, within the South American region, the most divergent group is PSH (and BOL in a lesser degree). The highest dental phenetic divergence was found between PNC vs. BOL (MMD = 0.229). Interestingly, PNC vs. PSH and PNC vs. PAA pairwise comparisons also show significantly high MMD values (MMD $=0.18$ and 0.089 , respectively). This was not expected since these three populations (i.e., PSH, PNC and PAA) came from the same country. They were geographically closest to each other relative to the VEN, BOL and $\mathrm{CHI}$ samples.

\section{Mean measure of divergence inter-regional analysis}

The present study also used the MMD to determine the degree of biological relatedness of early South Americans with several world popula-
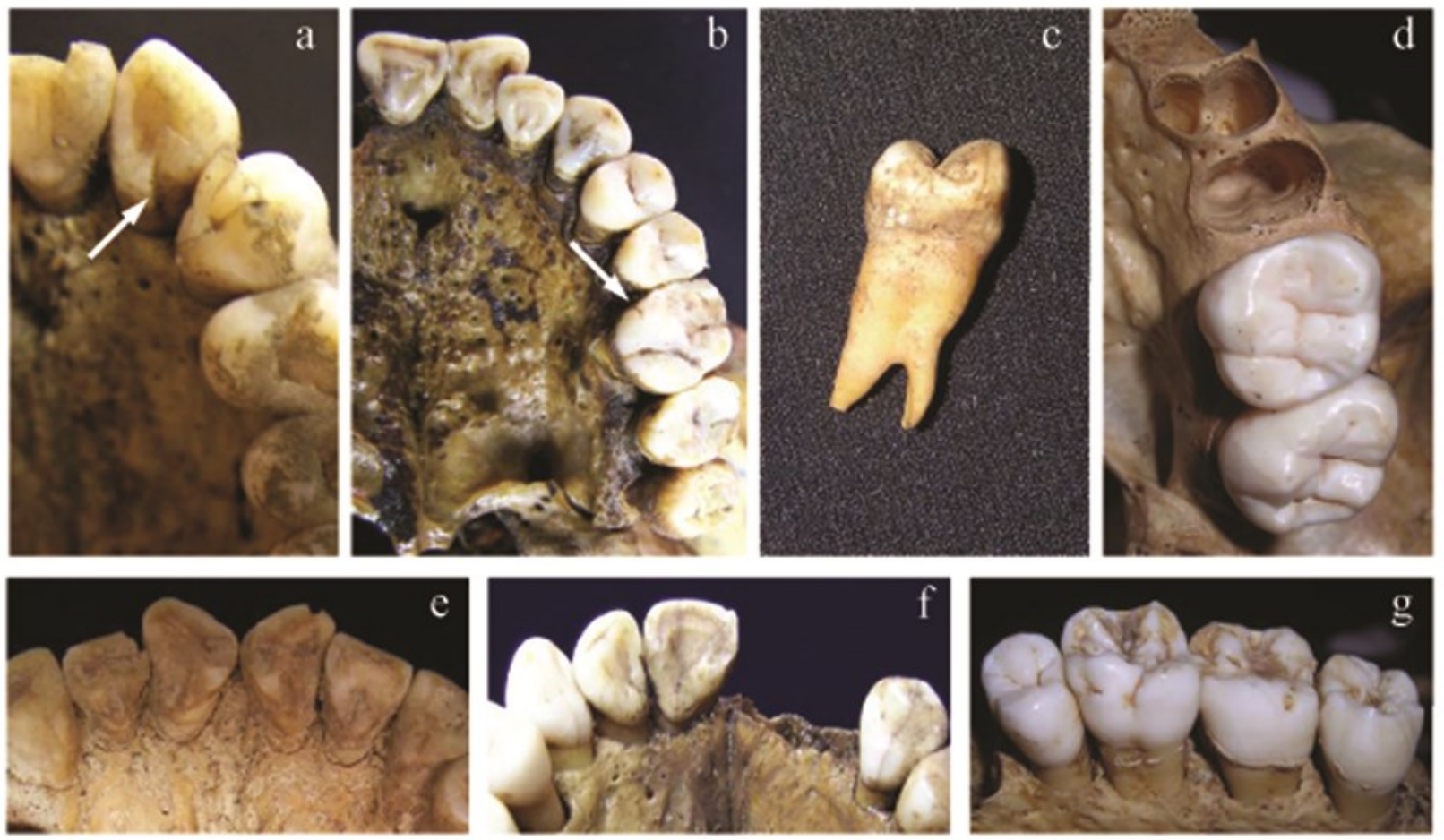

Fig. 2. Examples of morphological traits present in South American upper dentitions. (a) UI2 interruption groove (indicated by a white arrow); (b) UI1-UI2 shoveling, UI1-UC tuberculum dentale and UM1 Carabelli's trait (indicated by a white arrow); (c) two-rooted UP3; (d) tooth socket indicating the presence of a two-rooted UP3 (tooth itself is not seen); (e) UI1 winging; (f) UI1 shoveling; (g) UM1 Carabelli's trait. Left side depicted for figures (a-d) and (g). 
TABLE 3. Mean Measure of Divergence (MMD) for six South American samples based on 20 dental traits ${ }^{t}$

\begin{tabular}{ccccccc}
\hline & PSH & PNC & PAA & CHI & VEN & BOL \\
\hline PSH & - & & & & & \\
PNC & $\underline{0.177^{*}}$ & - & & & & \\
PAA & 0.021 & $\underline{0.089}$ & - & & & \\
CHI & 0.080 & 0.000 & 0.012 & - & & \\
VEN & 0.000 & 0.035 & 0.000 & 0.000 & - & - \\
BOL & 0.100 & $\underline{0.229}$ & 0.055 & 0.000 & 0.013 & \\
\hline
\end{tabular}

* Underlined MMD values are significant at $\mathrm{p} \leq 0.025$

t Root number UP3 not included in MMD analysis as data were not available for PAA (see Table 2)

tions exhibiting either the Sinodont or Sundadont dental pattern. The dental traits and breakpoints are summarized in Table 4 . The distance matrix based on MMD values is presented in Table 5. Examination of Table 5 , and its comparison with data from Table 3, indicates that trait choice does, in some cases, influence suggested affinities between groups derived from the MMD analysis. Based on the 12 dental traits listed in Table 4, the highest divergence within South American populations is between PSH vs. CHI (MMD = 0.190; the former MMD value based on 20 dental features was 0.080). Likewise, phenetic affinities between PNC vs. PAA, PNC vs. BOL and PAA vs. CHI have become either significantly higher or lower relative to those based on the 20-trait MMD analysis. On the other hand, $\mathrm{PNC}, \mathrm{CHI}$ and VEN remain den-

TABLE 4. Dental traits used in the inter-regional analysis

\begin{tabular}{|c|c|}
\hline Trait & Expression dichotomy \\
\hline Shoveling UI1 & ASU 0-6 / (+) = ASU 2-6 \\
\hline Double Shoveling UI1 & ASU 0-6 / $(+)=$ ASU 2-6 \\
\hline Odontome UP3-UP4 & ASU $0-1 /(+)=$ ASU 1 \\
\hline Hypocone UM2 & ASU $0-5 /(+)=$ ASU $2-5$ \\
\hline Cusp 5 UM1 & ASU $0-5 /(+)=$ ASU $1-5$ \\
\hline Carabelli's trait UM1 & ASU $0-7 /(+)=$ ASU $2-7$ \\
\hline Enamel extension UM1 & ASU $0-3 /(+)=$ ASU $2-3$ \\
\hline Groove pattern LM2 & $\operatorname{ASU} \mathrm{Y}, \mathrm{X},+/(+)=\mathrm{ASU} \mathrm{Y}$ \\
\hline Cusp number LM1 & ASU 0-6 / (+) = ASU 6 \\
\hline Cusp number LM2 & ASU 0-6 / (+) = ASU 4 \\
\hline Deflecting wrinkle LM1 & ASU $0-3 /(+)=$ ASU $1-3$ \\
\hline Cusp 7 LM1 & ASU $0-4 /(+)=$ ASU 1-4 \\
\hline
\end{tabular}

tally closest regardless of the number of traits used for testing relationships among groups.

Comparisons among other world populations reveal that PNC, CHI and VEN exhibit the closest affinities with Northern China. Paradoxically, the PAA sample shows significantly low MMD values with both Northern China and Southeast Asia $(\mathrm{MMD}=0.084$ and 0.089 , respectively). Likewise, although the MMD inter-regional analysis indicates that BOL is dentally closest to Northeast Siberia (MMD $=0.037)$, it also appears to be dentally similar to Southeast Asia (MMD $=0.063)$ and, to as lesser extent, to Northern China (MMD $=0.075)$. All these values are, however, statistically nonsignificant. Interestingly, PSH is the only of the six South American groups examined in this study that clearly shows the closest relationship with Southeast Asians (MMD = 0.094). Table 5 shows that, except for PSH, the highest divergence between South Americans and the other six world populations included in the MMD analysis is with pre-Hispanic Mexico. The degree of discordance of preHispanic Mexico and South America is particularly high in the case of $\mathrm{CHI}$, VEN and BOL.

This high degree of divergence is greater than would be expected if they share a recent common ancestor. However, it should be noted that relatively similar MMD values were observed for pairwise comparisons between Mexico and the other world populations. Thus, the unusual degree of divergence found between the 
South American and Mesoamerican samples may be an artifact of inter-observer error.

\section{DISCUSSION AND CONCLUSIONS}

This study characterized early South American dental morphology through the analysis of six pre- or proto-Hispanic Andean groups. Interestingly, although the importance of discrete dental traits for reconstructing human population history is widely acknowledged, a comprehensive study of dental variation in a broad geographical distribution of South American populations has not yet been undertaken. Most investigations have focused on North America, while research on South America has been scarce and narrow in scope (Goaz and Miller, 1966; Kieser and Preston, 1981; Turner and Bird, 1981; Sutter, 2005; Sutter and Verano, 2007). An accurate reconstruction of early human dispersal to the New World relies on the analysis of archaeological samples without presumed European admixture. This, however, is not an easy task, as the study of archaeological material usually precludes the incorporation of big sample sizes. Bad preservation, post mortem damage and excessive dental wear are additional problems faced by dental anthropologists interested in population history reconstructions. Although with these caveats in mind, this study represents an initial step towards the better understanding of the origins and biological affinities of early South Americans.

Examination of the pair-wise comparisons of the South American samples used in this study indicated a mean MMD of 0.054 . This value is remarkably similar to that found by Turner (1984) for Native North American populations (mean MMD = 0.051). Turner (1986) argued that dental morphological variation should be greater where human groups have lived the longest period of time. Although bigger sample sizes are needed in order to draw stronger conclusions, the similar levels of variation found within both North and South America would suggest a rapid occupation of the continent by the first American inhabitants. The PNC, CHI and VEN samples appear to be dentally similar, with trait frequencies closely resembling those of major Sinodont populations. The inter-regional analysis indicates that these three samples show greatest affinities with Northern China. On the other hand, PSH is the most di- vergent of the South American groups examined. Interestingly, trait frequencies of this group more closely approximate those of Sundadont populations from Southeast Asia. Frequencies of occurrence of the majority of BOL and PAA dental traits occupy an intermediate position within the range of overlap of the Sinodonty-Sundadonty dichotomy. In this context, although some dental homogeneity was found among PNC, CHI and VEN, the ambiguous position of BOL and PAA does not provide enough evidence to support or reject hypothesis 1 . However, the results of this investigation would falsify hypothesis 2, as South American populations do not necessarily follow the Sinodont dental pattern suggested by Turner (1986) and Greenberg et al. (1986) for all Native Americans and modern Northeast Asians. Although reported data were not big enough to directly contribute to the one-wave vs. multi-wave model conundrum, the results of this study are consistent with those derived from analyses of craniofacial variation among different world human populations (Lahr, 1995; González-José et al., 2008; Hubbe et al., 2011). These studies suggested that the appearance of the derived features present in modern Northeast Asians was a relatively recent event (ca. 7000 B.P.) and that the first migrants would have brought with them to the New World a more generalized and heterogeneous set of craniofacial and dental features (contra Turner, 1986, 1990; Greenberg et al., 1986). The fact that Native Americans do not necessarily follow a strict Sinodont dental pattern was also found by Haydenblit's (1996) analysis of four pre-Hispanic Mexican populations.

Finally, the greatest similarity of $\mathrm{PNC}, \mathrm{CHI}$ and VEN dentitions compared to the other South American groups was somewhat unexpected given the relatively ample geographic distances existing among these populations. Interestingly, all three (i.e., PNC, CHI and VEN) are derived from lowland and/or coastal regions. Furthermore, it was surprising to find that some of the highest degrees of dental divergence are between Peruvian-derived populations (PNC vs. PSH and PNCvs. PAA; see Table 3). As noted, the most variable populations (those whose trait frequencies cannot always be accommodated under the Sinodont pattern) are PSH, PAA and BOL. In contrast to PNC, $\mathrm{CHI}$ and VEN, the PSH, PAA and BOL samples are from very high altitude regions between ca. 


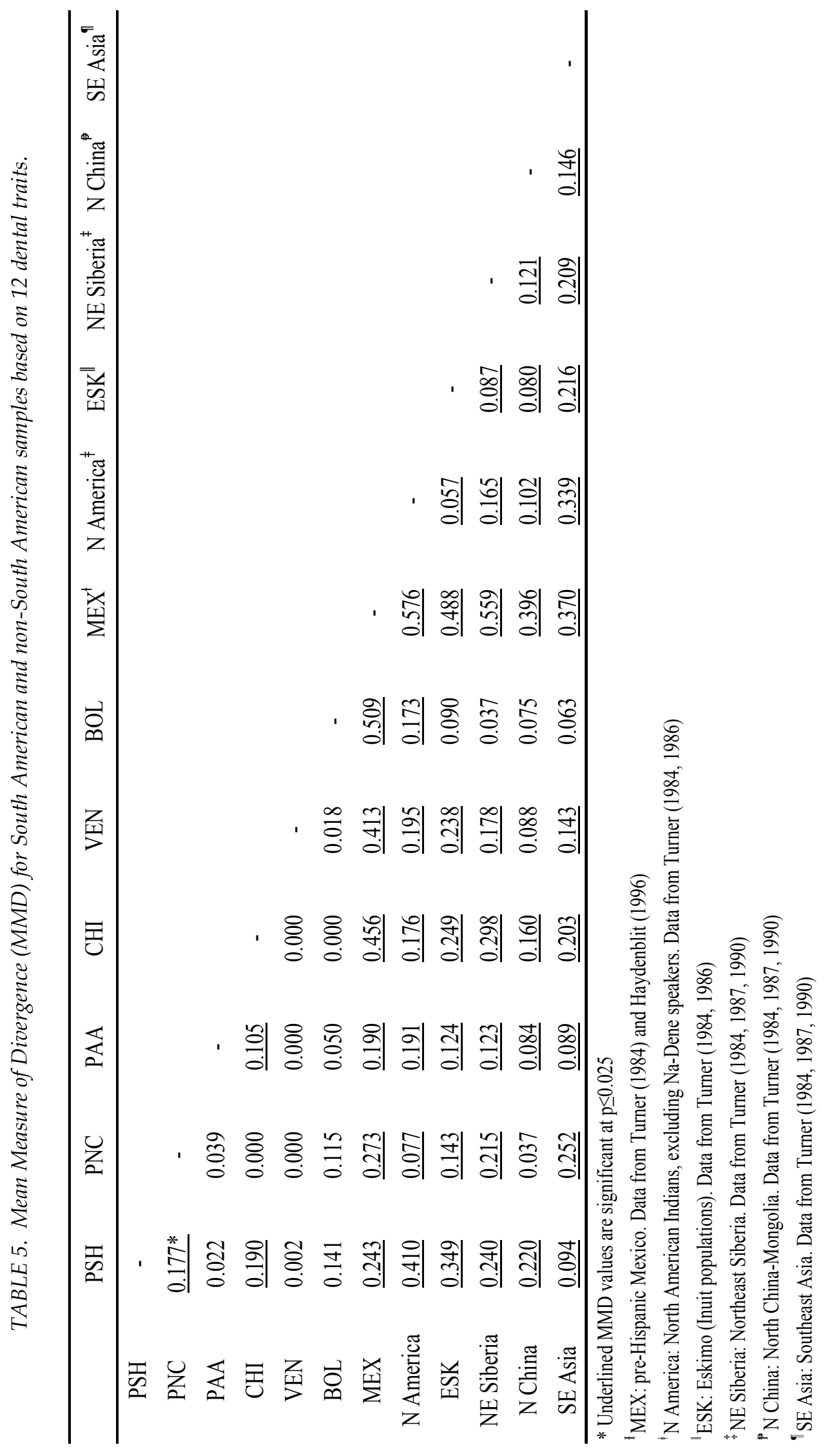


3,000 and 3,800 meters above the sea level). This suggests that, regardless of geographic distance, the observed pattern of dental variation may be the result of different rates of gene flow and genetic drift operating in the lowlands and highlands. Thus, while lowland and coastal regions would have favored high rates of gene flow among populations living in those areas, genetic drift would have played an important role in shaping the pattern of diversity present in highland populations. The debate of the initial peopling of the New World is far from being resolved, and many questions remain to be answered. Nevertheless, this study demonstrated that neither the Clovis-first nor the three-wave models for the settlement of the Americas by a highly specialized SinodontMongoloid human group is sufficient to encompass the pattern of dental morphological diversity present across the continent. To move forward past hypotheses need to be reevaluated through systematic and interdisciplinary studies. This study showed that dental morphology is a key area of research towards the accomplishment of these goals.

\section{ACKNOWLEDGEMENTS}

I would like to thank the staff of both the American Museum of Natural History, Anthropology Department (NY, USA) and the Instituto Nacional de Cultura (Chachapoyas, Peru) for allowing access to their collections, without which this study would not have been possible. I am especially grateful to Shara Bailey for the constant guidance and feedback to improve this study.

\section{LITERATURE CITED}

Adovasio JM, Pedler DR, Donahue J, Stuckenrath R. 1998. Two decades of debate on Meadowcroft Rockshelter. North Am Archaeol 19: 317-341.

Bandelier AF. 1904. Trephining in Bolivia. Am An thropol 6: 440-446.

Bandelier AF. 1910. The islands of Titicaca and Koati. New York: The Hispanic Society of America.

Baume RM, Crawford MH. 1978. Discrete dental traits in four Tlaxcaltecan Mexican populations. Am J Phys Anthropol 49: 351-360.

Bennett WC. 1937. Excavations at La Mata, Maracay, Venezuela. New York: American Museum of Natural History.
Berry AC, Berry RJ. 1967. Epigenetic variation in the human cranium. J Anat 101:361-379.

Bird JB. 1985. The preceramic excavations at the Huaca Prieta Chicama valley, Peru. New York: American Museum of Natural History.

Bird JB. 2006. Excavaciones en el norte de Chile. Santiago de Chile: Universidad Bolivariana.

Bonatto SL, Salzano FM. 1997. A single and early migration for the peopling of the Americas supported by mitochondrial DNA sequence data. Proc Natl Acad Sci 94: 1866-1871.

Dahlberg AA. 1945. The changing dentition of man. J Am Dent Assoc 32: 676-690.

Dahlberg AA. 1951. The dentition of the American Indian. In: Laughlin T, editor. The physical anthropology of the American Indian. New York: Viking Fund. p 138-176.

Dahlberg AA. 1963. Analysis of the American In dian dentition. In: Brothwell DR, editor. Dental anthropology. New York: Pergamon. p 149-177.

Dillehay TD. 1997. Monte Verde: A late Pleistocene settlement in Chile, vol. 2. The archaeology cal context and interpretation. Washington, DC: Smithsonian Institution Press.

Dillehay TD. 1999. The late Pleistocene cultures of South America. Evol Anthropol 7: 206-216.

Dillehay TD. 2000. The settlement of the Americas: A new prehistory. New York: Basic Books.

Dillehay TD. 2009. Probing deeper into first American studies. Proc Natl Acad Sci 106: 971978.

Fagundes NJR, Kanitz R, Eckert R, Valls ACS, Bogo MR, Salzano FM, Smith DG, Silva-Jr WA, Zago MA, Ribeiro-dos-Santos AK, Santos SEB, Petzl-Erler ML, Bonatto SL. 2008a. Mitochondrial population genomics supports a single preClovis origin with a coastal route for the peo pling of the Americas. Am J Hum Genet 82: 583592.

Fagundes NJR, Kanitz R, Bonatto SL. 2008b. A reevaluation of the Native American mtDNA genome diversity and its bearing on the models of early colonization of Beringia. PLoS ONE 3: e3157.

Goaz P, Miller M. 1966. A preliminary description of the dental morphology of the Peruvian Indian. J Dent Res 45: 106-119.

Goodyear AC. 2005. Evidence for pre-Clovis sites in the eastern United States. In: Bonnichsen R, Lepper BT, Stanford D, Waters MR, editors. Paleoamerican origins: Beyond Clovis. Texas: Texas A\&M University Press. p 103-112. 
Goebel T, Waters MR, O'Rourke DH. 2008. The late Pleistocene dispersal of modern humans in the Americas. Science 319: 1497-1502.

González-José R, Bortolini MC, Santos FR, Bonatto SL. 2008. The peopling of America: Craniofacial shape variation on a continental scale and its interpretation from an interdisciplinary view. Am J Phys Anthropol 137: 175-187.

Greenberg JH, Turner CG II, Zegura S. 1986. The settlement of the Americas: A comparison of the linguistic, dental and genetic evidence. Curr Anthropol 24: 477-497.

Hanihara T. 1992. Dental and cranial affinities among populations of East Asia and the Pacific: the basic populations in East Asia, IV. Am J Phys Anthropol 88: 163-182.

Hanihara T. 2008. Morphological variation of major human populations based on nonmetric dental traits. Am J Phys Anthropol 136: 169-182.

Harris EF, Sjøvold T. 2004. Calculation of Smith's mean measure of divergence for intergroup comparisons using nonmetric data. Dent Anthropol 17: 83-93.

Haydenblit R. 1996. Dental variation among four pre-Hispanic Mexican populations. Am J Phys Anthropol 100: 225-246.

Hoshower LM, Buikstra JE, Goldstein PS, Webster AD. 1995. Artificial cranial deformation at the Omo M10 site: A Tiwanaku complex from Moquegua Valley, Peru. Latin American Antiquity 6: 145-164.

Hubbe M, Harvati K, Neves W. 2011. Paleoamerican morphology in the context of European and East Asian late Pleistocene variation: implica tions for human dispersion into de New World. Am J Phys Anthropol 144: 442-453.

Imbelloni J. 1925. Deformaciones intencionales del craneo en Sud America. Rev Museo de la Plata XXVIII: 329-407.

Irish JD. 1993. Biological affinities of Late Pleistocene through modern African aboriginal populations: the dental evidence. Ph.D. dissertation. Tempe: Arizona State University.

Irish JD. 1997. Characteristic high- and lowfrequency dental traits in sub-Saharan African populations. Am J Phys Anthropol 102: 455-467.

Irish JD. 2010. The mean measure of divergence: its utility in model-free and model-bound analyses relative to the Mahalanobis D2 distance for nonmetric traits. Am J Hum Biol 22: 378-395.

Kieser JA, Preston CB. 1981. The dentition of the
Lengua Indians of Paraguay. Am J Phys Anthro pol 55: 485-490.

Lahr MM. 1995. Patterns of human diversification: implication for Amerindian origins. Yrbk Phys Anthropol 38: 163-198.

Lynch TF. 1983. The Paleoindians. In: Jennings J, editor. Ancient South Americans. New York: WH Freeman. p 87-137.

Martin PS. 1973. The discovery of America. Science 179: 969-974.

Meltzer DJ. 2004. Peopling of North America. In: Gillespie A, Porter SC, Atwater B, editors. The Quaternary Period in the United States. New York: Elsevier Science. p 539-563.

Moorrees CFA. 1957. The Aleut dentition. Cambridge: Harvard University Press.

Munizaga JR. 1987. Deformación craneana intencional en América. Rev Chilena de Antropologia 6: 113-147.

Neves WA, Prous A, González-José R, Kipnis R, Powell J. 2003. Early Holocene human skeletal remains from Santana do Riacho, Brazil: implycations for the settlement of the New World. J Hum Evol 45: 759-782.

Neves WA, Hubbe M. 2005. Cranial morphology of early Americans from Lagoa Santa, Brazil: Implications for the settlement of the New World. Proc Natl Acad Sci 102: 18309-18314.

Nichol CR, Turner CG II. 1986. Intra- and interobserver concordance in classifying dental mor phology. Am J Phys Anthropol 69: 299-315.

Pitulko VV, Nikolsky PA, Girya EY, Basilyan AE, TumskoyVE, Koulakov SA, Astakhov SN, Pavlova EY, Anisimov MA. 2004. TheYana RHS site: humans in the Arctic before the last glacial maximum. Science 303: 52-56.

Powell JF, Neves WA. 1999. Craniofacial morphology of the first Americans: pattern and process in the peopling of the New World. Yrbk Phys Anthropol 42: 153-188.

Pucciarelli HM, Sardi ML, Jimenez Lopez JC, Serrano C. 2003. Early peopling and evolutionary diversification in America. Quat Int 109: 123132.

Schjellerup I. 1997. Incas and Spaniards in the conquest of Chachapoyas. Archaeological and ethnohistorical research in the northeastern Andes of Peru. Goteborg: Goteborg University.

Schurr TG. 2004. The peopling of the New World: Perspectives from molecular anthropology. Ann Rev Anthropol 33: 551-583. 
Scott GR, Turner CG II. 1997. The anthropology of modern human teeth: dental morphology and its variation in recent human populations. Cambridge: Cambridge University Press.

Scott GR, Potter RHY, Noss JF, Dahlberg AA, Dahlberg TA. 1983. The dental morphology of Pima Indians. Am J Phys Anthropol 61: 13-31.

Sjøvold T. 1977. Non-metrical divergence between skeletal populations: the theoretical foundation and biological importance of C.A.B. Smith's mean measure of divergence. Ossa Suppl 4: 1133.

Sofaer JA, Niswander JD, MacLean CJ. 1972. Popu lation studies on the southwestern Indian tribes. $\mathrm{V}$. Tooth morphology as an indicator of biological distance. Am J Phys Anthropol 37: 357-366.

Sutter RC. 2005. The prehistoric peopling of South America as inferred from genetically controlled dental traits. Andean Past 7: 183-217.

Sutter RC, Verano JW. 2007. Biodistance analysis of the Moche sacrificial victims from Huaca de la Luna Plaza 3C: A matrix method test of their origins. Am J Phys Anthropol 132: 193-206.

Tamm E, Kivisild T, Reidla M, Metspalu M, Smith DG, Mulligan CJ, Bravi CM, Rickards O, Martinez-Labarga $C$, Khusnutdinova EK, Fedorova SA, Golubenko MV, Stepanov VA, Gubina MA, Zhadanov SI, Ossipova LP, Damba L, Voevoda MI, Dipierri JE, Villems R, Malhi RS. 2007. Beringian standstill and spread of Native American founders. PLoS ONE 2: e829.

Tommaseo M, Drusini A. 1984. Physical anthropology of two tribal groups of Amazonic Peru (with reference to artificial cranial deformation). Zeitschrift für Morphologie und Anthropologie 74: 315-333.

Turner CG II. 1971. Three-rooted mandibular first permanent molars and the question of the American Indian origins. Am J Phys Anthropol 34: 229-242.

Turner CG II. 1983. Dental evidence for the peopling of the Americas. In: Shutler R, editor. Early man in the New World. California: Sage Publications. p 147-157.

Turner CG II. 1984. Advances in the dental search for Native American origins. Acta Anthopogenetica 8: 23-78.

Turner CG II. 1986. The first Americans: the dental evidence. Natl Geog Res 2: 37-46.

Turner CG II. 1987. Late Pleistocene and Holocene population history of East Asia based on dental variation. Am J Phys Anthropol 73: 305-321.

Turner CG II. 1990. Major features of sundadonty and sinodonty, including some suggestions about East Asian microevolution, population history, and late Pleistocene relationships with Australian Aboriginals. Am J Phys Anthropol 82: 295-317.

Turner CG II. 1993. Southwest Indians: Prehistory through dentition. Natl Geog Res Expl 9: 32-53.

Turner CG II, Scott GR. 1977. Dentition of the Easter islanders. In: Dahlberg AA, Graber TM, editors. Orofacial Growth and Development. The Hague: Mouton. p 229-249.

Turner CG II, Bird J. 1981. Dentition of Chilean Paleo-Indians and peopling of the Americas. Science 212: 1053-1055.

Turner CG II, Nichol CR, Scout GR. 1991. Scoring procedures for key morphological traits of the permanent dentition. The Arizona State Univer sity Dental Anthropology System. In: Kelley MA, Larsen CS, editors. Advances in Dental Anthropology. New York: Willey Liss. P 13-31.

Wang S, Lewis CM, Jakobsson M, Ramachandran S, Ray N, Bedoya G, Rojas W, Parra MV, Molina JA, Gallo C, Mazzotti G, Poletti G, Hill K, Hurtado AM, Labuda D, Klitz W, Barrantes R, Bortolini MC, Salzano FM, Petzl-Erler ML, Tsuneto LT, Llop E, Rothhammer F, Excoffier L, Feldman MW, Rosenberg NA, Ruiz-Linares A. 2007. Genetic variation and population structure in $\mathrm{Na}-$ tive Americans. PLoS Genet 3: 2049-2067.

Weiss P. 1961. Osteologia cultural, practicas cefalicas. Anales de la Facultad de Medicina 2: 133276.

Zegura SL, Karafet TM, Zhivotovsky LA, Hammer MF. 2004. High-resolution SNPs and microsatellite haplotypes point to a single, recent entry of Native American Y chromosomes into the Americas. Mol Biol Evol 21: 164-175. 